\title{
Ultrastructure and stable carbon isotope composition of the hydrothermal vent mussels Bathymodiolus brevior and B. sp. affinis brevior from the North Fiji Basin, western Pacific
}

\author{
Nicole Dubilier*, Reinhard Windoffer, Olav Giere \\ Zoologisches Institut und Zoologisches Museum, Universität Hamburg, Martin-Luther-King Platz 3, D-20146 Hamburg, Germany
}

\begin{abstract}
In hydrothermal vents of the western Pacific several mytilid bivalve species of the genus Bathymodiolus attain a dominating ecological role. The ultrastructure of the symbiosis in the vent mytilid $B$. brevior as well as in an undescribed species $B$. sp. affinis brevior from a deep-sea hydrothermal vent site in the North Fiji Basin of the southwestern Pacific was studied. The abundance of symbionts was strikingly different in the 2 species, with $B$. brevior gills housing low numbers of bacteria that occurred singly in membrane-bound vacuoles, while $B$. sp. aff brevior gills contained numerous symbionts with up to 12 bacteria per vacuole. Bacterial vacuoles at the outermost region of the bacteriocytes occasionally ( $B$. brevior) or regularly ( $B$. sp. aff. brevior) showed an open connection to the exterior, ambient seawater. In both species only a single symbiont morphotype without intracytoplasmatic membranes occurred, suggesting that these mytilids harbor only chemoautotrophic, sulfur-oxidizing bacteria. Stable carbon isotope ratios provided further information on the trophic interactions between the endosymbionts and their hosts. The $\delta^{13} \mathrm{C}$ values of $B$. brevior gill tissues ranged from -30.8 to $-35.8 \%$ and were significantly more negative than in non-symbiotic tissues, indicating that the symbionts may not account for the sole source of dietary carbon in these associations.
\end{abstract}

KEY WORDS: Symbiosis - Mytilid $\cdot$ Chemoautotrophic bacteria

\section{INTRODUCTION}

The mytilid bivalve Bathymodiolus thermophilus Kenk \& Wilson (1985) was first discovered in 1977 at deep-sea hydrothermal vents in the Galapagos Rift Zone of the eastern Pacific (Corliss \& Ballard 1977, Corliss et al. 1979). Since then many new Bathymodiolus species from cold-water methane/sulfide seeps and hydrothermal vents in the Atlantic and Pacific oceans have been described (Cosel \& Métivier 1994, Hashimoto \& Okutani 1994, Craddock et al. 1995). The genus Bathymodiolus is characterized by a considerable flexibility in its sources of nutrition. All members of the genus contain intracellular symbiotic bacteria in their large, fleshy gills (reviewed in Fisher 1990, Nelson \& Fisher 1995). In some species these sym-

•E-mail: ndubilie@mpi-bremen.de bionts are thioautotrophic (i.e. sulfur-oxidizing, $\mathrm{CO}_{2}$ fixing), in some methanotrophic (i.e. methane-utilizing) and in others both thioautotrophic and methanotrophic bacteria can co-occur (Fisher et al. 1993, Distel et al. 1995). In addition to their ability to gain nutrition from their symbionts, all Bathymodiolus species have retained a gut and at least 2 species are able to filter feed and assimilate organic material from the ingested food (Page et al. 1990, 1991, Le Pennec et al. 1995)

While Bathymodiolus species from the eastern Pacific have been studied intensively (see reviews cited above), little is known of the biology of symbiotic mytilids from the western Pacific. Beyond general descriptions of hydrothermal vent communities in the southwestern Pacific (Desbruyères et al. 1994) and some stable isotope data on unidentified mytilid species of the Mariana Trough (Van Dover \& Fry 1989) and Okinawa Trough (Kim \& Sakai 1991), only a few stud- 
ies have examined the symbioses of western Pacific Bathymodiolus species in more detail (Pranal et al. 1995, 1997). Until recently, investigations were hampered by a lack of information on the taxonomy of hydrothermal vent mytilids from the western Pacific. Two Bathymodiolus species from hydrothermal vents in the Lau and North Fiji Basin in the southwestern Pacific have now been identified, $B$. brevior and $B$. elongatus (von Cosel \& Métivier 1994), which can cooccur at some sites. In this paper we describe the ultrastructure of the symbiosis in the vent mytilid $B$. brevior as well as in an undescribed species Bathymodiolus sp. affinis brevior (R. von Cosel pers. comm.) from a hydrothermal vent site in the North Fiji Basin. Stable carbon isotope ratios of $B$. brevior provide further information on the trophic interactions between the endosymbionts and their hosts.

\section{MATERIALS AND METHODS}

Specimen collection. The mytilid bivalve Bathymodiolus brevior was collected in the North Fiji Back Arc Basin, southwest Pacific, from the LHOS hydrothermal vent site $\left(16^{\circ} 59.65^{\prime} \mathrm{S}, 173^{\circ} 54.73^{\prime} \mathrm{E}\right)$ during the 'Sonne 99' cruise in January 1995 (Auzende et al. 1995, Halbach et al. 1995). Based on photographic surveys with a video-controlled deep-towed sled, the LHOS site is a composite vent field of $200 \times 200 \mathrm{~m}$ with 5 more or less active vents and at least 4 wide patches of diffuse venting along an open fissure. A TV-controlled grab (GTV) lowered from the ship to $2000 \mathrm{~m}$ water depth was used for specimen collection. The specimens described in this study were retrieved from 4 grabs (GTV Stns 91, 92, 98, and 115) that were all taken within approx. 50 to $100 \mathrm{~m}$ of each other. The number and diversity of hydrothermal vent species recovered in these grabs was low at Stns 91 (2 B. brevior, 1 B. sp. aff. brevior) and $92(1 \mathrm{~B}$. sp. aff. brevior and 3 Thyasira sp.), intermediate at $\operatorname{Stn} 98$ (38 B. brevior) and highest at $\operatorname{Stn} 115$ [40 B. brevior, at least 8 Ifremeria nautilei (a gastropod with symbiotic bacteria in its gills, Windoffer \& Giere 1997), and 1 unidentified pogonophore] (Michael Türkay, Forschungsinstitut Senkenberg, Frankfurt, Germany, pers. comm.).

Species identification was provided by Rudo von Cosel (Muséum National d'Histoire Naturelle, Paris, France). Bathymodiolus brevior has been well described (von Cosel \& Métivier 1994) while the characterization of $B$. sp. aff. brevior is preliminary and based on only 1 juvenile and 1 adult specimen (von Cosel pers. comm.). This possibly new species is characterized by a somewhat narrower shell than $B$. brevior (but much shorter and stouter than in $B$. elongatus). The ligament does not end as abruptly as in $B$. brevior and $B$ elongatus. Voucher specimens have been deposited in the Mollusc Department of the Muséum National d'Histoire Naturelle.

Microscopy. For microscopic examinations on Bathymodiolus sp. aff. brevior, 1 juvenile from Stn 91 (with a shell length of $30 \mathrm{~mm}$ ) and 1 adult from Stn 92 (with a shell length of $87 \mathrm{~mm}$ ) were available. For $B$. brevior, 4 adults from Stn 98 (with shell lengths from 64 to $97 \mathrm{~mm}$ ) were available. The gill filaments were dissected and fixed in $4 \%$ paraformaldehyde and $3 \%$ glutaraldehyde in $0.1 \mathrm{M}$ cacodylate buffer with $15 \%$ sucrose $(\mathrm{pH} 7.4)$. The tissues were rinsed in the same buffer, post-fixed in $1 \%$ osmium tetroxide, and stored in the same buffer for up to several months before dehydration in acetone and embedment in SPURR (Spurr 1969). For light microscopy, semithin sections were stained with toluidine blue. For electron microscopy, ultrathin sections were stained with uranyl acetate and lead citrate, and examined with a Zeiss EM 109-S2

A quantitative analysis of bacterial abundance was not possible because of the limited number of specimens available for study. Instead, bacterial abundances in Bathymodiolus brevior and B. sp. aff. brevior were compared by counting the number of bacteria per host cell on representative electron micrographs of the mid-filament region of the gill.

Stable carbon isotope analysis. Only Bathymodiolus brevior specimens were available for carbon isotope analysis. Three adults from Stn 98 (with shell lengths from 84 to $89 \mathrm{~mm}$ ) and 3 adults from Stn 115 (with shell lengths from 93 to $108 \mathrm{~mm}$ ) were examined. At Stn 115 each mytilid carried 1 individual of the commensal polychaete Branchypolynoe pettibonae Miura \& Hashimoto (1991) in its pallial cavity. The mytilids were frozen at $-20^{\circ} \mathrm{C}$ immediately after collection, thawed in the laboratory and dissected into 3 fractions: gills, foot tissue, and the rest of the soft tissue. The symbiotic polychaetes $(n=3)$ were pooled and treated as 1 tissue. The tissues were overlaid with $0.1 \mathrm{~N} \mathrm{HCl}$ for $24 \mathrm{~h}$, rinsed in aqua dest. overnight, and dried at $60^{\circ} \mathrm{C}$. Samples were combusted to carbon dioxide at $1050^{\circ} \mathrm{C}$ in a stream of oxygen using a Heraeus CHN analyzer attached to a Finnigan MAT Delta mass spectrometer with a reproducibility of less than $0.15 \%$. Results are expressed as parts per thousand in relation to the Pee Dee Belemnite (PDB) standard.

\section{RESULTS}

\section{Gill structure}

The general morphology of the Bathymodiolus brevior gill corresponded to previous descriptions of gills from other members of this genus (Fiala-Médioni et al. 
1986, Fisher et al. 1987, 1993). The symbionts occurred in the gills which were composed of numerous filaments, with abundant ciliation at their frontal apex. The filaments were inter-connected by at least 7 or 8 rows of ciliary tufts on their lateral faces. The lateral faces of the filaments were composed of bacteriocytes, which contained the intracellular symbionts and sym- biont-free intercalary cells interspersed irregularly between the bacteriocytes. In comparison to other mytilid symbioses, $B$. brevior bactenocytes housed much lower abundances of symbionts, with 10 to 60 bactena per host cell visible in cross-sections of the mid-filament region (Fig. 1A). The symbionts were found in the apical or surface region of the bacterio-
$\mathbf{B}$
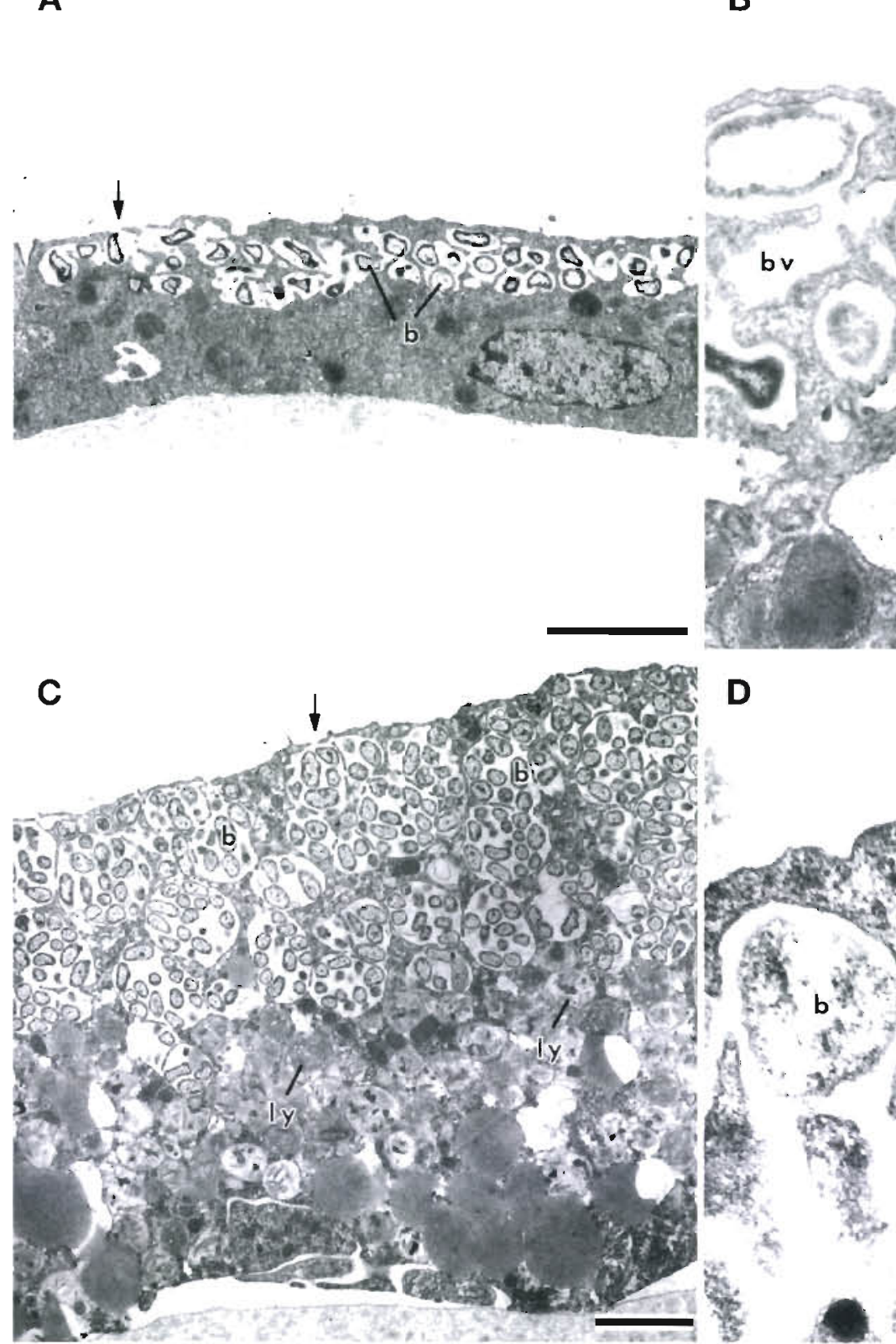
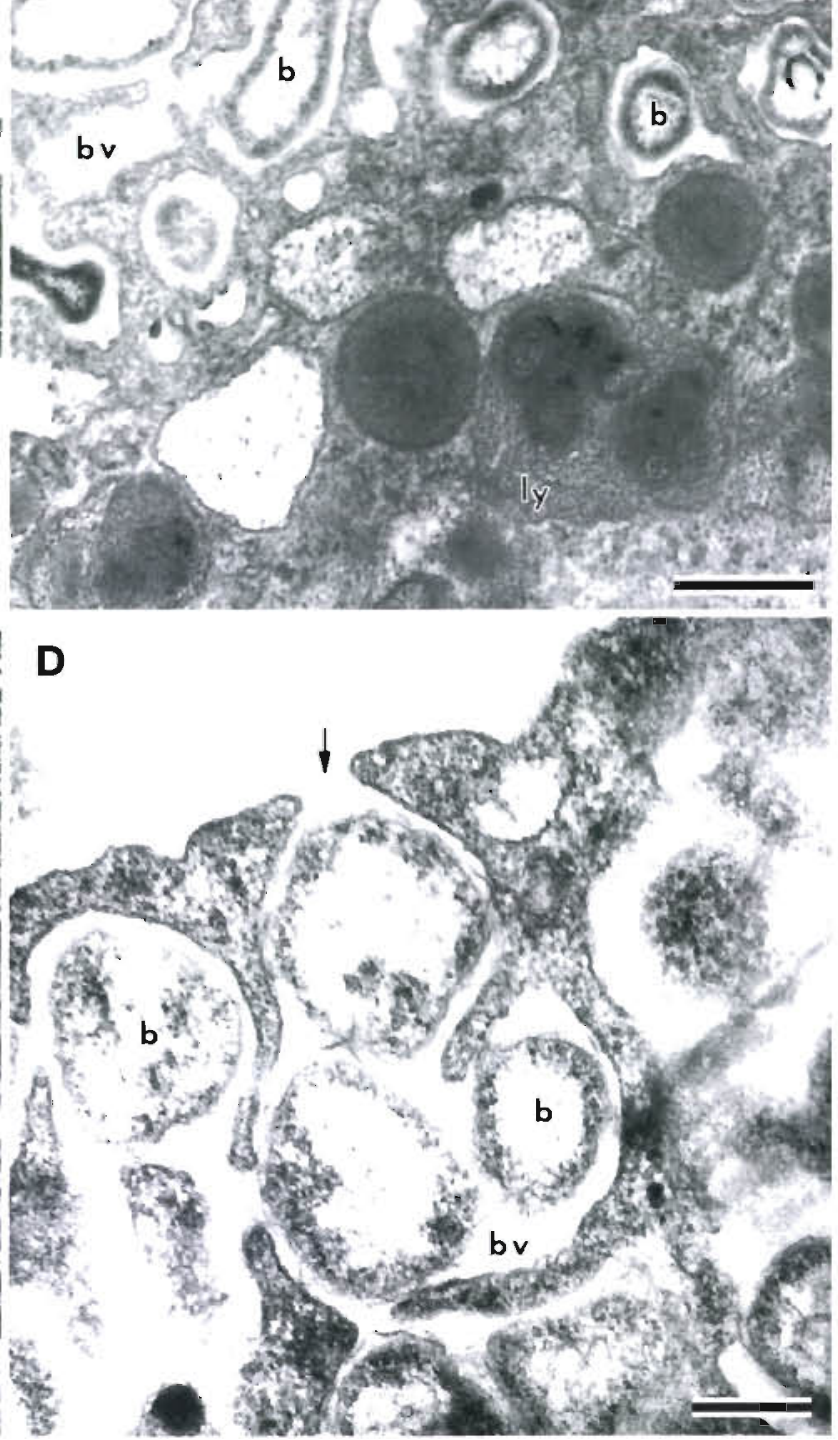

Fig. 1. (A, B) Bathymodiolus brevior and (C, D) B sp affmis brevior Gill tissues from the mid-filament region with symbiotic bacteria. $B$. brevior bacteriocytes are narrow with low symbiont abundances and bactena are housed singly in membranebound vacuoles. B. sp. aff. brevior bactenocytes are considerably broader with much higher numbers of symbionts, and vacuoles that contain up to 12 bacteria. Open connections of peripheral bacterial vacuoles to the extenor occur regularly (arrows in $\mathrm{A}$, $\mathrm{C}$, and D), and the host membrane is intact at these openings (D) b bacteria, bv bactenal vacuole. ly lysosome Scale bars (A) $2 \mu \mathrm{m}$, (B) $0.5 \mu \mathrm{m}$, (C) $2 \mu \mathrm{m}$, (D) $02 \mu \mathrm{m}$ 
cytes in vacuoles that were often interconnected, with usually only 1 symbiont per vacuole (Fig. 1B). Occasionally, symbiont vacuoles at the outermost region of the bacteriocytes showed an open connection to the exterior (Fig. 1A). The symbionts were small cocci or short rods ranging from 0.25 to $0.75 \mu \mathrm{m}$ in diameter, with a cell wall typical of Gram-negative bacteria, and did not contain membranes or other distinctive structures in their cytoplasm. Towards the basal part of the bacteriocytes electron-dense, membrane-bound lysosomal structures were found that could contain numerous internal membranes (Fig. 1A, B).

While the gross morphology of the Bathymodiolus brevior and $B$. sp. aff. brevior gill was similar, the abundance of symbionts was dramatically different. The bacteriocytes in $B$. sp. aff. brevior harbored many more bacteria than $B$. brevior, with 100 to 350 bacteria per host cell visible in cross-sections of the mid-filament region (Fig. 1C). Correspondingly, the bacteriocytes were much broader than those of $B$. brevior and their basal regions were more densely packed with lysosomal structures (Fig. 1C). In further contrast to B. brevior, each vacuole contained more than 1 symbiont, with as many as 12 bacteria occurring in a single vacuole. Open connections of bacterial vacuoles to the exterior occurred more often than in B. brevior (Fig. 1C, D). As in B. brevior, the host membrane at these openings always appeared intact (Fig. 1D). The morphology and size of the symbionts was similar in $B$. sp. aff. brevior and $B$. brevior. Ultrastructural differences between the juvenile and adult $B$. sp. aff. brevior specimens were not observed.

\section{Stable carbon isotope ratios}

Stable carbon isotope ratios were determined separately for the gills, foot, and other soft body tissues (rest) from a total of 6 Bathymodiolus brevior individuals from Stns 98 and 115 (Table 1). At Stn 98 gill tissues ranged from -30.8 to $-32.1 \%$, at Stn 115 from -35.2 to $-35.8 \%$. Gill tissues were consistently more negative

Table 1. Bathymodiolus brevior. Stable carbon isotope values of mussel tissues $\left(\delta^{13} \mathrm{C}\right.$, in $\%$. Specimens were dissected into 3 parts: gills, foot tissue, and the rest of the soft body

\begin{tabular}{|c|c|c|c|}
\hline & Gills & Foot & Rest \\
\hline \multicolumn{4}{|l|}{ Stn 98} \\
\hline B. brevior 1 . & -31.1 & -30.6 & -31.0 \\
\hline B. brevior 2 & -30.8 & -25.7 & -30.7 \\
\hline B. brevior 3 & -32.1 & -30.8 & -31.5 \\
\hline \multicolumn{4}{|l|}{ Stn 115} \\
\hline B. brevior 1 & -35.8 & -32.4 & -33.5 \\
\hline B. brevior 2 & -35.2 & -32.0 & -33.8 \\
\hline B. brevior 3 & -35.7 & -32.2 & -33.9 \\
\hline
\end{tabular}

(i.e. lighter or enriched in ${ }^{12} \mathrm{C}$ ) than foot and other soft body tissues at both stations. The average difference between gills and the 2 other tissues was significant at Stn 115 ( $p<0.05$, Wilcoxon, Mann and Whitney $U$-test), with the means of the $\delta^{13} \mathrm{C}$ values from the 3 individuals differing by $1.8 \%$ between gills and rest, and $2.8 \%$ between gills and foot.

The Bathymodiolus brevior tissues from Stn 115 were significantly more negative than those from Stn 98 ( $p<0.05$, Wilcoxon, Mann and Whitney $U$-test), with average differences between the 2 stations ranging from $4.2 \%$ in gill tissues to $3.2 \%$ in foot tissues and $2.7 \%$ in other soft body tissues (rest). Only mytilids from Stn 115 carried the commensal polychaete scale worm Branchypolynoe pettibonae. The $\delta^{13} \mathrm{C}$ value of 3 pooled polychaetes was, at $-33.2 \%$, in the same range as $B$. brevior tissues from Stn 115, indicating that the worms and their hosts derive their nutrition from the same trophic sources.

\section{DISCUSSION}

As in all other Bathymodiolus symbioses (reviewed in Fisher 1990, Nelson \& Fisher 1995), the symbionts found in the gills of $B$. brevior and $B$. sp. aff. brevior were intracellular within membrane-bound vacuoles and had a cell envelope resembling that of Gram-negative bacteria. The ultrastructure of the symbionts indicates that they are prokaryotic cells, as in all other hydrothermal vent animals with intracellular symbionts (Cavanaugh 1994).

In other Bathymodiolus symbioses the prokaryotic symbionts have been identified as thioautotrophic or methanotrophic based on morphological, biochemical, enzymatic, and molecular data, with each species harboring either one or both trophic types (Cavanaugh et al. 1992, Fisher et al. 1993, Distel et al. 1995, Pranal et al. 1997. Pond et al. 1998). In B. brevior, the stable carbon isotope values of -25.7 to $-35.8 \%$ are in the range of values reported for both thioautotrophic and methanotrophic Bathymodiolus symbioses and thus do not provide unambiguous information on the trophic nature of the symbionts (Nelson \& Fisher 1995). The morphological data is more informative and suggests that both $B$. brevior and B. sp. aff. brevior harbor only thioautotrophic symbionts because (1) only a single symbiont morphotype was observed and (2) this morphotype did not contain intracytoplasmic membranes which are characteristic for all methanotrophic symbionts (Cavanaugh 1992). Further indications for the presence of sulfur-oxidizing symbionts are high concentrations of the amino acid thiotaurine and (n-7) monounsaturated phospholipid fatty acids in the gills of $B$. brevior (Pranal et al. 1995, 1997). 
In comparison to other Bathymodiolus species, the abundance of endosymbiotic bacteria in $B$. brevior was remarkably low, with most of the bacteriocytes in the mid-filament region showing only very few symbionts per cross-section. [Compare, however, with Pranal et al. (1997) who, based on fatty acid data, suggest symbiont biomass values in $B$. brevior of the same order of magnitude as those estimated for $B$. thermophilus.] Low symbiont abundances were observed in all $B$. brevior specimens examined in this study. Unfortunately, these specimens were all collected at the same site (Stn 98) so that the influence of different microhabitats and nutrient conditions on intraspecific symbiont morphology could not be investigated in this study. Surprisingly, a detailed study of the relationship between a host's microenvironment and its symbiont ultrastructure and distribution has, to our knowledge, not been published. In the case of $B$. brevior, the low abundances of symbionts appear to be characteristic for this association, as similarly low numbers of symbionts were observed in $B$. brevior specimens collected several years earlier from a different hydrothermal vent site in the North Fiji Basin (see Fig. 2 in Pranal et al. 1995). This conclusion is further supported by the fact that $B$. sp. aff. brevior individuals collected within the same hydrothermal vent area during this study harbored high abundances of symbionts. Clearly, bacterial abundance varies in a species-specific manner in Bathymodiolus hosts, with the number of symbionts per vacuole ranging from one to hundreds (Fisher \& Kelly 1992).

In both Bathymodiolus brevior and B. sp. aff. brevior, vacuoles at the apical ends of the bacteriocytes were occasionally open to the exterior ambient seawater. At these sites, the host cell membrane was always clearly intact, indicating that these openings were not caused by fixation artefacts. While not described in other Bathymodiolus symbioses, similar openings have been observed in 2 symbiotic gastropod species from western Pacific hydrothermal vent sites, Alviniconcha hessleri and Ifremeria nautilei (Endow \& Ohta 1989, Windoffer \& Giere 1997), and it has been suggested that this arrangement mirrors a possible evolutionary pathway from extra- to intracellular symbioses (Windoffer \& Giere 1997). In A. hessleri, staining experiments with ruthenium red showed that the external medium only reaches the bacteria at the periphery while the symbionts in the basal part of the bacteriocytes are truly enclosed (Endow \& Ohta 1989). Unfortunately, in this study fresh material needed for these staining experiments was not available.

The stable carbon isotope ratio $\left(\delta^{13} \mathrm{C}\right)$ of an animal's tissues reflects its source of organic carbon and can therefore be used to examine trophic relationships. Stable carbon isotope ratios in Bathymodiolus brevior ranged from -25.7 to $-35.8 \%$ and were similar to ratios determined in undescribed symbiotic mytilid species from the western Pacific (-26.1 to $-34.8 \%$; Van Dover \& Fry 1989, Kim \& Sakai 1991). The B. brevior values are consistent with the hypothesis of a nutrition source for these mytilids that is not surface-derived photosynthetic carbon ( -12 to $-22 \%$; Van Dover \& Fry 1989$)$. The $\delta^{13} \mathrm{C}$ values of $B$. brevior resemble those found in free-living thioautotrophic bacteria and in other bivalve groups which harbor thioautotrophic symbionts (reviewed in Fisher 1995, Nelson \& Fisher 1995). In Bathymodiolus symbioses with methanotrophic symbionts, much more negative ratios ranging from -37 to $-78 \%$ have been reported (Fisher 1995, Nelson \& Fisher 1995). However, interpretation of stable carbon isotope ratios is complicated by the fact that, in some Bathymodiolus species with both thioautotrophic and methanotrophic symbionts, $\delta^{13} \mathrm{C}$ values are in the same range as in mytilids with only thioautotrophic symbionts (Cavanaugh et al. 1992, Pond et al. 1998). Thus, while amino and fatty acid (Pranal et al. 1995, 1997) as well as morphological data (see above) indicate that $B$. brevior harbors only thioautotrophic symbionts, its stable carbon isotope composition does not provide unequivocal support for this conclusion.

Bathymodiolus brevior specimens from Stn 115 had consistently more negative $\delta^{13} \mathrm{C}$ values than mytilids from Stn 98. These differences could be due to a more negative $\delta^{13} \mathrm{C}$ composition of dissolved inorganic carbon (DIC) at Stn 115. Stable carbon isotope composition of DIC can vary by as much as $3 \%$ between different vent microhabitats (Childress \& Fisher 1992). However, the more likely explanation for the observed differences of 2.7 to $4.2 \%$ in $B$. brevior $\delta^{13} \mathrm{C}$ values between Stns 98 and 115 is a higher input of chemosynthetic carbon at $\operatorname{Stn} 115$. This assumption is further supported by the higher number and diversity of hydrothermal vent species collected at Stn 115 than Stn 98 (see 'Materials and methods').

As in all other Bathymodiolus species, B. brevior has retained its digestive apparatus and it is likely that it has at least a rudimentary ability to filter feed and ingest food, as observed in other symbiotic mytilids (Page et al. 1990, 1991, Le Pennec et al. 1995). This assumption is supported by the difference in $\delta^{13} \mathrm{C}$ values of symbiotic gill and non-symbiotic foot tissues in $B$. brevior (rest tissues are not considered here, as they might have been contaminated with minor bits of gill tissue). In B. brevior, non-symbiotic foot tissues were as much as $5.1 \%$ and on average $2.8 \%$ more positive than symbiotic gill tissues. If the only source of dietary carbon were the symbionts then foot tissues should have, if anything, slightly more negative $\delta^{13} \mathrm{C}$ values than gill tissues, as isotopic fractionation of carbon between an animal and its food source is minimal, with 
at most a $1 \%$ more negative $\delta^{13} \mathrm{C}$ in animal tissues relative to diet $\delta^{13} \mathrm{C}$ occurring (Rau 1985). An isotopic fractionation of $1 \%$ would increase the average difference between $B$. brevior gill and foot tissues to $3.8 \%$, lending further support to the assumption that the symbionts do not account for the sole source of dietary carbon in these associations. Indeed, the low abundances of bacteria in these associations make it hard to imagine that the symbionts could provide their hosts with sufficient nutrition. The relationship between symbiont abundance and stable carbon isotope composition has, to our knowledge, not yet been described. Further studies on the intra- and interspecific variation in symbiont distribution and trophic relationships within the genus Bathymodiolus are clearly necessary in order to better understand the ecology of these important members of hydrothermal vent macrofauna.

Acknowledgements. We thank the captain and crew of the RV 'Sonne 99' for their assistance and cooperation. We are indebted to Rudo von Cosel (Muséum National d'Histoire Naturelle, Daris, France) for specimen identifiration, Monika Segl (University of Bremen, Germany) for her help with $\delta^{13} \mathrm{C}$ measurements, and Gisela Wegener from our lab for her valuable assistance in microscopical preparations. This study was supported by the Ministry of Education, Science, Research, and Technology (BMBF) of Germany (grant 03G0099A).

\section{LITERATURE CITED}

Auzende JM, Halbach P, Allspach A, Becker K, Blum N, Bonnier $O$, Vangerven $M$, Halbach $M$, Koschinsky A, Lange D, Madureira MJ, Manoutsoglou E, Mrazek J, Münch U, Pratt C, Rahders E, Vanreusel A, Richter S, Seifert $T$, Spangenberg $T$, Stenzler J, Thiermann $F$, Türkay $M$, Windoffer R (1995) Tectonic, magmatic and hydrothermal activity around the triple-junctions of the North Fiji Basin (16 $6^{\circ} 50^{\prime} \mathrm{S}-173^{\circ} 30^{\prime} \mathrm{E}$ and $16^{\circ} 30^{\prime} \mathrm{S}-176^{\circ} 10^{\prime} \mathrm{E}$ ) (SW Pacific): HYFIFLUX cruise. CR Acad Sci Paris Sér Ila 321:239-246

Cavanaugh CM (1992) Methanotroph-invertebrate symbioses in the marine environment: ultrastructural, biochemical and molecular studies. In: Murrell JC, Kelly DP (eds) Microbial growth on $C_{1}$ compounds. Intercept, Andover, p 315-328

Cavanaugh CM (1994) Microbial symbiosis: patterns of diversity in the marine environment. Am Zool 34:79-89

Cavanaugh CM, Wirsen CO, Jannasch HW (1992) Evidence for methylotrophic symbionts in a hydrothermal vent mussel (Bivalvia: Mytilidae) from the Mid-Atlantic Ridge. Appl Environ Microbiol 58:3799-3803

Childress JJ. Fisher CR (1992) The biology of hydrothermal vent animals: physiology, biochemistry, and autotrophic symbioses. Oceanogr Mar Biol Annu Rev 30:337-441

Corliss JB, Ballard RD (1977) Oases of life in the cold abyss Nat Geogr Mag 1.52:440-453

Corliss JB, Dymond J, Gordon LI, Edmund JM, von Herzen RP, Ballard RD, Green $K$, Williams D, Baimbridge A, Crane K, van Andel TH (1.979) Submarine thermal springs on the Galapagos Rift. Science 203:1073-1083

Craddock C, Hoeh. WR, Gustafson RG, Lutz RA, Hashimoto J, Vrijenhoek RJ (1995) Evolutionary relationships among deep-sea mytilids (Bivalvia: Mytilidae) from hydrothermal vents and cold-water methane/sulfide seeps. Mar Biol 121: $477-485$

Desbruyères D, Alayse-Danet AM, Ohta S, Scientific Parties of BIOLAU and STARMER Cruises (1994) Deep-sea hydrothermal communities in Southwestern Pacific backarc basins (the North Fiji and Lau Basins): composition, microdistribution and food web. Mar Geol 116:227-242

Distel DL, Lee HKW, Cavanaugh CM (1995) Intracellular coexistence of methano- and thioautotrophic bacteria in a hydrothermal vent mussel. Proc Natl Acad Sci USA 92 9598-9602

Endow K, Ohta S (1989) The symbiotic relationship between bacteria and a mesogastropod snail, Alviniconcha hesslen, collected from hydrothermal vents of the Mariana Back-Arc Basin. Nihon Biseibutsu Seitai Gaikkaiho (Bull Jap Soc Microb Ecol) 3:73-82

Fiala-Médioni A, Métivier C, Herry A, Le Pennec M (1986) Ultrastructure of the gill of the hydrothermal-vent mytilid Bathymodiolus sp. Mar Biol 92:65-72

Fisher CR (1990) Chemoautotrophic and methanotrophic symbioses in marine invertebrates. Rev Aquat Sci 2:399-436

Fisher CR (1995) Toward an appreciation of hydrothermalvent animals: their environment, physiological ecology, and tissue isotope values. Geophys Monogr 91:297-316

Fisher CR, Brooks JM, Vodenichar JS, Zande JM, Childress JJ. Burke RAJ (1993) The co-occurrence of methanotrophic and chemoautotrophic sulfur-oxidizing bacterial symbionts in a deep-sea mussel. PSZN I: Mar Ecol 14: $277-289$

Fisher CR, Childress JJ, Oremland RS, Bidigare RR (1987) The importance of methane and thiosulfate in the metabolism of the bacterial symbionts of two deep-sea mussels. Mar Biol 96:59-71

Fisher CR, Kelly KE (1992) Intracellular location and fate of bacterial symbionts in vent and seep mytilids. Am Zool 32:52 A

Halbach P, Auzende JM, Türkay M (1995) Das HyfifluxProjekt. Geowissenschaftliche und biologische Hydrothermalforschung im Nord-Fiji-Becken. Geowissenschaften 13 : $243-248$

Hashimoto J, Okutani T (1994) Four new mytilid mussels associated with deepsea chemosynthetic communities around Japan. Venus Jpn J Malacol 53:61-83

Kenk VC, Wilson BR (1985) A new mussel (Bivalvia: Mytilidae) from hydrothermal vents in the Galapagos Rift zone Malacologia 26:253-271

Kim ES, Sakai H (1991) Stable isotopic ratios of deep-sea hydrothermal vent animals at the Mid-Okinawa Trough. Ocean Res 13:19-30

Le Pennec M, Beninger PG, Herry A (1995) Feeding and digestive adaptations of bivalve molluscs to sulphide-rich habitats. Comp Biochem Physiol 111A:183-189

Miura T, Hashimoto J (1991) Two new branchiate scaleworms (Polynoidae: Polychaeta) from the hydrothermal vent of the Okinawa Trough and the volcanic seamount off Chichijima Island. Proc Biol Soc Wash 104:166-174

Nelson DC, Fisher CR (1995) Chemoautotrophic and methanotrophic endosymbiotic bacteria at deep-sea vents and seeps. In: Karl DM (ed) The microbiology of deep-sea hydrothermal vents. CRC Press, Boca Raton, p 125-167

Page HM, Fiala-Médioni A, Fisher CR, Childress JJ (1991) Experimental evidence for filter-feeding by the hydrothermal vent mussel, Bathymodiolus thermophilus. Deep Sea Res 38:1455-1461

Page HM, Fisher CR, Childress JJ (1990) Role of filter-feeding in the nutritional biology of a deep-sea mussel with 
methanotrophic symbionts. Mar Biol 104:251-257

Pond DW, Bell MV, Dixon DR, Fallick AE, Segonzac M, Sargent JR (1998) Stable-carbon-isotope composition of fatty acids in hydrothermal vent mussels containing methanotrophic and thiotrophic bacterial endosymbionts. Appl Environ Microbiol 64:370-375

Pranal V, Fiala-Médioni A, Colomines JC (1995) Amino acid and related compound composition in two symbiotic mytilid species from hydrothermal vents. Mar Ecol Prog Ser 119:155-166

Pranal V, Fiala-Médioni A, Guezennec J (1997) Fatty acid characteristics in two symbiont-bearing mussels from deep-sea hydrothermal vents of the south-western Pacific J Mar Biol Assoc UK 77:473-492

Rau GH $(1985){ }^{13} \mathrm{C} /{ }^{12} \mathrm{C}$ and ${ }^{15} \mathrm{~N} /{ }^{14} \mathrm{~N}$ in hydrothermal vent

Editorial responsibility: Otto Kinne (Editor),

Oldendorf/Luhe, Germany organisms: ecological and biogeochemical implications. Biol Soc Wash Bull 6:243-247

Spurr AR (1969) A low-viscosity epoxy resin embedding medium for electron microscopy. J Ultrastr Res 26:31.

Van Dover CL, Fry B (1989) Stable isotopic compositions of hydrothermal vent organisms. Mar Biol 102:257-263

von Cosel R, Métivier B (1994) Three new species of Bathymodiolus (Bivalvia: Mytilidae) from hydrothermal vents in the Lau Basin and the North Fiji Basin, Western Pacific, and the Snake Pit Area, Mid-Atlantic Ridge. Veliger 37 : $374-392$

Windoffer R, Giere $O$ (1997) Symbiosis of the hydrothermal vent gastropod Ifremeria nautilei (Provannidae) with endobacteria-structural analyses and ecological considerations. Biol Bull (Woods Hole) 193:381-392

Submitted: September 18, 1997; Accepted: February 17, 1998 Proofs received from author(s): April 16, 1998 